\title{
Risk, Uncertainty and Entrepreneurship: Evidence from a Lab-in-the-Field Experiment
}

\author{
Martin Koudstaall,2 \\ Randolph Sloofl,2 \\ Mirjam van Praag ${ }^{1,3}$
}

\footnotetext{
1 Tinbergen Institute, the Netherlands;

2 Faculty of Economics and Business, University of Amsterdam, the Netherlands;

3 Copenhagen Business School, Denmark.
} 
Tinbergen Institute is the graduate school and research institute in economics of Erasmus University Rotterdam, the University of Amsterdam and VU University Amsterdam.

More TI discussion papers can be downloaded at http://www.tinbergen.nl

Tinbergen Institute has two locations:

Tinbergen Institute Amsterdam

Gustav Mahlerplein 117

1082 MS Amsterdam

The Netherlands

Tel.: +31(0)205251600

Tinbergen Institute Rotterdam

Burg. Oudlaan 50

3062 PA Rotterdam

The Netherlands

Tel.: +31(0)10 4088900

Fax: $+31(0) 104089031$

Duisenberg school of finance is a collaboration of the Dutch financial sector and universities, with the ambition to support innovative research and offer top quality academic education in core areas of finance.

DSF research papers can be downloaded at: http://www.dsf.nl/

Duisenberg school of finance

Gustav Mahlerplein 117

1082 MS Amsterdam

The Netherlands

Tel.: +31(0)20 5258579 


\title{
Risk, Uncertainty and Entrepreneurship: Evidence From a Lab-in-the-Field Experiment
}

\author{
Martin Koudstaal \\ University of Amsterdam \& Tinbergen Institute \\ Randolph Sloof \\ University of Amsterdam \& Tinbergen Institute \\ Mirjam van Praag * \\ Copenhagen Business School \& Tinbergen Institute
}

October 17, 2014

\begin{abstract}
Theory predicts that entrepreneurs have distinct attitudes towards risk and uncertainty, but empirical evidence is mixed. To better understand the unique behavioral characteristics of entrepreneurs and the causes of these mixed results, we perform a large 'lab-in-the-field' experiment comparing entrepreneurs to managers - a suitable comparison group - and employees $(n=2288)$. The results indicate that entrepreneurs perceive themselves as less risk averse than managers and employees, in line with common wisdom. However, when using experimental incentivized measures, the differences are subtler. Entrepreneurs are only found to be unique in their lower degree of loss aversion, and not in their risk or ambiguity aversion. This combination of results might be explained by our finding that perceived risk attitude is not only correlated to risk aversion but also to loss aversion. Overall, we therefore suggest using a broader definition of risk that captures this unique feature of entrepreneurs; their willingness to risk losses.
\end{abstract}

Key words: Entrepreneurs, managers, risk aversion, loss aversion, ambiguity aversion, labin-the field experiment

JEL codes: L26, C93, D03.

\section{Introduction}

One of the most salient dimensions of entrepreneurship is risk and uncertainty. Economic theory predicts that entrepreneurs, as business owning residual claimants, are less averse towards risk and

\footnotetext{
${ }^{*}$ Corresponding author. Correspondence: Kilevej 14a; 2000, Frederiksberg, Denmark. Email address: mvp.ino@cbs.dk. Previous versions of this paper have been presented at seminars and workshops at the Hebrew University, Copenhagen Business School and SAID Business School of the University of Oxford.
} 
uncertainty than others (Cantillon, 1755; Knight, 1921; Kirzner, 1973 and Kihlstrom and Laffont, 1979). Entrepreneurs assume business risks in the most uncertain environments. Their income, wealth, satisfaction and social status are dependent on the outcomes of their decisions in uncertain situations. ${ }^{1}$ On top of that, most of the entrepreneurs' investment portfolios are totally undiversified (Moskowitz and Vissing-Jorgensen, 2002), also due to capital constraints in the market for entrepreneurial finance. ${ }^{2}$ Notwithstanding this theoretical prediction, the body of empirical evidence on risk, uncertainty and entrepreneurship is rather mixed (see Holm et al., 2013, Appendix Table). To reconcile these earlier findings we conduct a lab-in-the-field experiment among 910 entrepreneurs, 397 managers and 981 employees in the Netherlands.

The recent study by Holm et al. (2013) is most related to ours. They also perform a large-scale lab-in-the-field experiment with incentives to determine how attitudes towards risk and uncertainty distinguish entrepreneurs from others. They distinguish between strategic and non-strategic risk. Strategic risk covers measures of trust and competition. Non-strategic risk is measured in terms of risk aversion and ambiguity aversion. They find that entrepreneurs are more willing to assume strategic risk but are not more willing to assume risks lacking a strategic, interactive character. Our study is distinct from theirs in three ways. First, we compare entrepreneurs (in a Western country as opposed to China) to managers as well as employees and not to the local population at large. Second we use both a survey-based and an experimental, incentivized measure of risk aversion. Third, we also measure loss aversion and find that this is the most important difference between entrepreneurs and managers in the domain of risk and uncertainty.

More generally, our study can be characterized by the following four distinguishing features. First, we elicit peoples' risk attitudes using two different measures: one is an 'objective' measure which is incentived and experimental, based on a multiple pricelist (MPL) elicitation method (in the style of Holt and Laury, 2002). The other is 'subjective', i.e., survey-based and self-assessed (Dohmen et al., 2011). Both are well-established within their categories and have been extensively validated and used. ${ }^{3}$ So far, studies testing differences in risk attitudes between entrepreneurs and others have either used an incentivized experimental measure in the Holt and Laury style, or a nonincentivized self-assessed survey-based measure in the spirit of Dohmen et al., 2011). Interestingly, all studies using experimental measures of risk aversion find no differences between entrepreneurs and the control group, whereas most of the other studies do find differences supporting the common wisdom that entrepreneurs are less risk averse. By using both measures we can contribute to the

\footnotetext{
${ }^{1}$ For further references, see e.g., Cantillon (1755); Say (1803); Knight (1921); Petersen and Rajan (1994); Berger and Udell (1998); Heaton and Lucas (2000); Moskowitz and Vissing-Jorgensen (2002); Gentry and Hubbard (2004); Heaton and Lucas (2004) and Parker (2009).

${ }^{2}$ E.g., Evans and Jovanovic (1989); Holtz-Eakin et al. (1994a,b); Hvide and Møen (2010); Fairlie and Krashinsky (2012) and Schmalz et al. (2013).

${ }^{3}$ See Filippin and Crosetto (2014) for a meta-analysis of studies using the Holt and Laury measure to relate risk to gender. For a validity test of the Dohmen et al. (2011) measure, see Dohmen et al. (2007), Bonin et al. (2007), Caliendo et al. (2009), Lonnqvist et al. (2011) and Beauchamp et al. (2012). Overall, the Dohmen question scores highly on re-test reliability within-person and has been shown to be virtually stable over re-test intervals ranging from three weeks up to almost two years (see Dohmen et al., 2007, and Lonnqvist et al., 2011). However, a recent study by Brachert and Hyll (2014) shows that occupational choices may affect the Dohmen test outcomes.
} 
explanation of the mixed findings so far. ${ }^{4}$

Second, besides comparing entrepreneurs and others with respect to risk, we also try to understand in what related aspects entrepreneurs and managers are different. We consider both loss aversion, allowing an asymmetric effect of losses and gains on peoples' utility, and ambiguity aversion, i.e. probabilities are unknown and there is genuine uncertainty in the Knightian sense. ${ }^{5}$ By relating the three incentivized experimental measures of uncertainty (risk, loss and ambiguity aversion) to the survey-based self-assessed measure of risk aversion we can extend our understanding of the relationship between objective and subjective measures of risk. For instance, we find that subjects' views of what is risk aversion is in fact a mixture of what economists call risk, loss and ambiguity aversion.

Third, we use a double control group. Instead of comparing entrepreneurs with the general population, we use two tightly defined control groups, viz. managers and employees. ${ }^{6}$ We are especially interested in the first control group. Behavioral characteristics of managers and entrepreneurs have been compared in various studies (e.g. Brockhaus, 1980; Schere, 1982; Begley, 1995; Busenitz and Barney, 1997 and Stewart Jr. et al., 1999), because the two groups are arguably very similar. Both are responsible for strategic and complex decisions and are managing the employees in their companies (if any). Therefore they are likely to be similar in terms of many observable aspects, such as education, age, and labor market participation. We indeed observe that the managers and entrepreneurs in our sample are very similar, whereas the differences in background characteristics with employees are sizeable. If these differences extend to unobserved characteristics, such as motivation, perseverance or wealth, no fair comparison can be made between entrepreneurs and non-entrepreneurs. Therefore, employing two relatively similar control groups allows for a cleaner test of behavorial differences between entrepreneurs and others. Using the two control groups may also show to what extent differences are related to the control group used. ${ }^{7,8}$

\footnotetext{
${ }^{4}$ Examples of studies using Holt and Laury style elicitation of risk attitude are Elston and Harrison, 2006; Macko and Tyszka, 2009; Sandri et al., 2010; Burmeister-Lamp et al., 2012 and Holm et al. (2013). Examples of studies on risk and entrepreneurship using non-experimental measures of risk attitude are Hull et al., 1980; Brockhaus, 1980; Caird, 1991; Begley, 1995; Koh, 1996; Sarasvathy et al., 1998; Stewart Jr. et al., 1999; Van Praag and Cramer, 2001; Uusitalo, 2001; Cramer et al., 2002; Djankov et al., 2006, 2007 and Caliendo et al. (2010).

${ }^{5}$ Gächter et al. (2010) is the only study we are aware of that also compares the degree of loss aversion across occupational groups. They find that entrepreneurs are less loss averse on average than others in the risky choice category. Moreover, managers appear less loss averse than blue-collar workers but not than white-collar workers. The degree of ambiguity aversion of entrepreneurs has been compared to students and non-entrepreneurs by Koh (1996), Macko and Tyszka (2009) and Holm et al. (2013) and with managers by Schere (1982). With the exception of Holm et al. (2013), who do not report a significant difference, the general finding seems to be that entrepreneurs are better able to cope with ambiguous situations than both managers and non-entrepreneurs are.

${ }^{6}$ Many studies have used rather unspecified control groups, such as Van Praag and Cramer (2001); Uusitalo (2001); Cramer et al. (2002); Elston and Harrison (2006); Djankov et al. (2006, 2007); Macko and Tyszka (2009); Caliendo et al. (2010); Sandri et al. (2010); Burmeister-Lamp et al. (2012) and Holm et al. (2013).

${ }^{7}$ Many studies that have compared entrepreneurs and managers are relatively old and rely on small samples and self-assessed measures of risk attitude. The overall findings are mixed, too. Brockhaus (1980) and Busenitz and Barney (1997) found no differences between the two groups, whereas both Begley (1995) and Stewart Jr. et al. (1999) report lower levels of risk aversion among entrepreneurs than managers. Furthermore, a meta-analytical review by Stewart Jr. and Roth (2001) concludes that managers are more risk averse than entrepreneurs, although this conclusion is challenged by Miner and Raju (2004) who conclude that the role of risk propensity in entrepreneurship remains unresolved.

${ }^{8}$ In a comparison of managers and employees, Graham et al. (2013) show that managers have a lower risk aversion
} 
Fourth, following the debate in the literature about who can be considered an entrepreneur (see for instance Parker, 2009; Levine and Rubinstein, 2012 or Henrekson and Sanandaji, 2014), we verify our main findings by using various alternative definitions of the entrepreneur. In our basic sample, an 'entrepreneur' is someone who founded, inherited or has taken over a company that s/he is currently (co-)managing and of which s/he has at least $5 \%$ of the shares. ${ }^{9}$ We use alternative subsamples that are based on 'stricter' definitions of entrepreneurship (see Lindquist et al., 2013), i.e. those that are arguably more successful and thus more similar to the 'Schumpeterian' entrepreneur. Subsamples used incude: (i) incorporated entrepreneurs (Levine and Rubinstein, 2012), making up almost half of the sample, (ii) entrepreneurs with an above median number of employees and (iii) entrepreneurs with above average income. In comparable ways, we also use various more selective definitions of our control groups. Managers in the basic sample are defined as employees in firms not started up by the respondent, and having at least two direct reports under their responsibility. The stricter definitions limit the sample to: (i) CEOs (17\%), (ii) managers with an above median number of direct reports and (iii) managers with above median income. Finally, employees are the people who work in organizations and do not belong to the groups of entrepreneurs and managers (when using the baseline, i.e., least 'strict' definitions for entrepreneurs and managers).

Our findings tell the following story. Entrepreneurs perceive themselves as more risk tolerant than managers who see themselves, in turn, as being more risk tolerant than employees. This ranking is consistent with most of the previous studies using subjective measures of risk. However, based on the objective MPL risk aversion measure, entrepreneurs and managers have similar risk attitudes, but are both less risk averse than employees. When analyzing the differences in loss and ambiguity aversion across the three groups, we show that loss aversion is the missing piece. Whereas all three groups have similar degrees of ambiguity aversion, entrepreneurs have a significant lower level of loss aversion than the two other groups. We reconcile these different findings by relating the subjective risk measure to all three experimental measures. All three appear to be strongly related to what people self-assess to be their risk attitude. Respondents thus have a notion of 'risk' that is different from economists, and more a mixture of risk and uncertainty. Hence, not only could a distinct degree of risk aversion of managers and entrepreneurs explain the differences in their self-assessed risk attitude, these differences may also relate to differences in loss or ambiguity aversion. All these results are independent of the various definitions we use of entrepreneurs and managers. In some cases, limiting the sample to more successful entrepreneurs even strengthens the results.

Our two main conclusions are basically two sides of the same coin. First, entrepreneurs do differ from managers and employees in their attitude towards risk and uncertainty, but in a rather subtle way. Second, subjective self-assessed measures of risk attitude measure more than the economists' strict notion of risk aversion alone. The distinguishing trait of entrepreneurs thus becomes apparent only after realizing that there is more to risk and uncertainty than risk aversion per se.

\footnotetext{
than employees.

${ }^{9}$ Five percent is the cutoff ownership that the tax authority calls 'a substantial interest'. However, we find that $88 \%(65 \%)$ of the entrepreneurs in our sample holds at least $30 \%$ (51\%) of the company shares.
} 
We think it is rather intuitive that entrepreneurs are indeed different from managers in the way they deal with risk and uncertainty and that the difference is related to how losses 'loom larger than corresponding gains' (Kahneman and Tversky, 1979, 1984; Tversky and Kahneman, 1992). The entrepreneur's position is one in which much more is at stake to be lost than in the role of a manager. However, our study cannot reveal why entrepreneurs are found to be less loss averse than managers. Although the general consensus tends to be that preferences in the domain of risk and uncertainty are stable (see e.g. Borghans et al., 2008, Sahm, 2012, and Fouarge et al., 2014), a recent study by Brachert and Hyll (2014) cast serious doubt on the stability of these preferences. Therefore, the descriptive nature of the study prevents us from drawing causal conclusions. Entrepreneurs might either be less loss averse types or might become less loss averse when becoming an entrepreneur. In a similar vein, a managerial context might also affect managerial loss aversion considering the asymmetry in blame and credit within organizations (Swalm, 1966; Kahneman and Lovallo, 1993). We acknowledge that this is a limitation of our study. However, this limitation notwithstanding, we believe that our study not only contributes to the literature by further clarifying the unique behavioral features of entrepreneurs in comparison with managers and employees, but also by offering an explanation for the previous mixed results in this area.

In what follows, Section 2 discusses design and measurement issues. In Section 3 we present the descriptive statistics of our sample. Section 4 reports the empirical findings. Section 5 provides a discussion and conclusion.

\section{Measurement and sampling}

\subsection{Measurement of risk, loss and ambiguity aversion}

Entrepreneurship is associated with risk bearing, uncertainty, gains and losses. The classic economists and philosophers who laid the foundation of thinking about entrepreneurship all but Schumpeter defined the entrepreneur either as a risk bearer (Cantillon, 1755; Say, 1803; Marshall, 1930), an uncertainty bearer (Knight, 1921), or as agents who are less inclined to avoid losses (Knight, 1921; Marshall, 1930). ${ }^{10}$ Intuitively these three different concepts can be understood as follows.

Risk aversion is a concept with a very specific meaning in economics. It is the willingness of people to sacrifice expected payoffs to circumvent taking risks. In other words, it measures the

\footnotetext{
${ }^{10}$ The earliest philosophic thinker about entrepreneurship Cantillon (1755) defined the entrepreneur as a risk bearer as a consequence of buying and selling at uncertain prices. Say's entrepreneur (1803) is a risk bearer because of the risk of losing capital and reputation due to the likelihood of failure. Hence, Say defines entrepreneurship in terms of the risk of losses rather than of gains. Marshall's view on entrepreneurship (1930) is the most common one: entrepreneurs are responsible for assuming the business risks associated with their enterprise. Marshall also acknowledges that a few extremely high prices will have a disproportionately great attractive force (Marshall, 1930, p. 554) "because risk lovers are more attracted by the prospects of a great success than they are deterred by the fear of failure" . Thus, also Marshall pays particular attention to loss aversion. Knight (1921) was the first to explicitly distinguish between risk and true uncertainty (ambiguity). He defines the entrepreneur as the particular kind of individual who bears uncertainty because business decisions practically never concern calculable probabilities (Van Praag, 1999, p. 322).
} 
extent to which the utility of a guaranteed payoff (for instance 50) is higher than the utility derived from a proposition with the same expected reward obtained with risk (for instance 100 with $50 \%$ probability and 0 with $50 \%$ probability). Risk aversion is involved in decision making situations where a probability can be assigned to each possible outcome of the situation.

Loss aversion refers to the notion that decision makers prefer to avoid losses over acquiring gains. Loss aversion was first demonstrated by Kahneman and Tversky in their prospect theory (Kahneman and Tversky, 1979, 1984). Loss aversion implies that losing 50 will decrease utility or satisfaction by more than the increase in utility or satisfaction that is associated with a (windfall) gain of 50. Loss aversion explains the well-known endowment effect (Kahneman et al., 1990) that people value the goods and assets they own higher than identical goods and assets they do not own.

Ambiguity aversion is also known as uncertainty aversion and refers to a preference for risks with known probabilities over and above risks with unknown probabilities (true Knightian uncertainty), e.g., Ellsberg (1961) and Holm et al. (2013). Ambiguous events have a greater degree of uncertainty than risky events because not only is the outcome uncertain, but also the probability of the realization of that outcome and, as a consequence, the expected payoff.

\section{Risk aversion}

To measure risk aversion empirically, we rely on two measures. The first experimental, choice-based measure is obtained by using the multiple price list (MPL) format of Dohmen et al. (2010), which originates from Holt and Laury (2002). Participants are confronted with a list of ten decisions between two options: a risky one with known probabilities (Option A) and a safe one (Option B). In each of the ten cases option A corresponds to gaining $€ 300$ with a $50 \%$ chance or gaining $€ 0$ with a $50 \%$ chance. The safe option B on the other hand gradually increases from $€ 25$ to $€ 250$ (see Figure 1). Instead of asking each participant to reveal their preferences for every decision, we asked each participant to indicate their switching point. ${ }^{11}$ For example, a possible answer that could be selected was "I prefer Option A in decision 1 and Option B in 2-10". Risk-neutrality is implied in this setup by a switching point from Option A to Option B at the 6th decision (€150 for sure).

The second, survey-based measure of risk aversion is copied from Dohmen et al. (2011). Participants indicate their self-perceived willingness to take risks in general, as well as in the two sub-domains of career and financial matters. We employed a 0-10 scale, where 0 stood for "Not at all willing to take risks" and 10 for "Very willing to take risks". ${ }^{12}$

\section{$<$ INSERT FIGURE 1 HERE $>$}

\footnotetext{
${ }^{11}$ Others have also adapted MPL formats eliciting a switching point from the respondents rather than having them make separate and similar decisions in a row (see e.g. Dohmen et al., 2011 and Gneezy and Pietrasz, 2014). We opted for using switching points because the experiment includes multiple MPL formats and we assume that entrepreneurs, managers and employees are time-constrained (more so than students in a laboratory who have given up the hour of the experiment anyway).

${ }^{12}$ In the design of the questionnaire, this question was widely spaced from the incentivized risk measure, which came first. The question about willingness to take risk in general is of main interest, the ones about career and financial matters are used for robustness checks.
} 


\section{Loss aversion}

Loss aversion is measured by means of the MPL applied by Fehr and Goette (2007) and Gächter et al. (2010), which in essence is like the Holt and Laury price list but also includes negative payoffs. In this case, Option A consists of a $50 \%$ probability of receiving $€ 6$ and a $50 \%$ probability of losing an amount between $€ 1$ - $€ 10$. When selecting the safe Option B, participants receive $€ 0$ (see Figure 2). Again, we are interested in the respondents' switching points.

Overall, the small stakes in these lotteries ensure that risk aversion cannot convincingly explain the choice behavior in these decisions, as risk aversion in such small-stake lotteries would imply extreme degrees of risk aversion in high-stake gambles (e.g. Rabin, 2000; Wakker, 2005; Fehr and Goette, 2007 and Wakker, 2010). Rabin (2000) therefore argues that under expected utility theory, people should be risk neutral in such small stakes gambles. We emphasize in our survey that selecting Option A entails a real loss of money.

\section{$<$ INSERT FIGURE 2 HERE >}

\section{Ambiguity aversion}

Our measure of ambiguity aversion is taken from Fox and Tversky (1995) and Gneezy and Pietrasz (2014) and uses an MPL structure again. In each of the ten decisions, we present participants with an Urn A with 50 red balls and 50 black balls, and an Urn B which has an unknown distribution of red and black balls. The selection of Urn A pays off $€ 300$ if a red ball is drawn and $€ 0$ if it is black. If participants choose to select Urn B, payments vary between $€ 250$ and $€ 475$ if a red ball is drawn and is $€ 0$ in the case of a black ball, see Figure 3.

\section{$<$ INSERT FIGURE 3 HERE $>$}

\subsection{Sampling}

According to Holm et al. (2013, p. 1676), obtaining a large-scale experiment involving hundreds of entrepreneurs and managers "...would be a demanding undertaking anywhere in the world. Owners and CEOs of established firms are rarely willing to devote their scarce time to time-consuming academic studies." They observe that some earlier studies solved this problem by studying the self-employed, others by using small (convenience) samples, whereas they themselves have gone to China to perform an incentivized experiment with affordable monetary awards. Their sample includes 700 private enterprises, excluding start-ups and small-scale household firms, and a random sample of 200 individuals as control group. They note that their control group is not ideal and that 
"...the ideal control group would be one that is identical to the entrepreneurs except that they are not entrepreneurs" (p. 1677).

We took a different route to obtain a large-scale sample in a Western country (the Netherlands), including a control group that is rather similar to the group of entrepreneurs. We decided to bring the lab to the field and obtain responses from participants online. This practice is not uncommon when aiming for a substantial response from the field (see e.g., DeMartino and Barbato, 2003; Block and Koellinger, 2009; Graham et al., 2013). We were able to reach qualifying participants through our extensive network of the Amsterdam Center for Entrepreneurship (ACE). For entrepreneurs, we collaborated with "Synpact", a company that has the digital Rolodex of a random selection of small and medium sized enterprises, including 15,000 entrepreneurs in the Netherlands. The Rolodex is supported by frequent contacts through a wide variety of training programs and conferences. The 15,000 entrepreneurs all received an invitation to participate in the online research. ${ }^{13}$ For managers, we collaborated with a large and highly reputed training center ("De Baak"), which is part of the largest and influential employers' organization ("VNO-NCW, MKB-Nederland") in the Netherlands. The training center was willing to send our invitation to participate in the research to all managers they have in file, a total of 5,888 . The same invitation was sent to a sample of 7,850 employees, which were recruited via a Dutch market research agency with access to over 70,000 Dutch employees.

Invitations to participate were sent out to the groups of entrepreneurs and managers on October 1 (Round 1) and to the employees on November 4 (Round 2). All groups had exactly 14 days to respond and non-respondents at that stage received a reminder after 7 days. Out of all people who received the mailing, 910 entrepreneurs, 397 managers and 981 employees completed the survey. Response rates were thus in the range of 6-12\%. These are comparable to the European response rates in e.g. Graham et al. (2013). A comparison of respondents with non-respondents based on the available observables (age and gender) yields no significant differences for entrepreneurs and managers. For the responding employees, however, females were slightly oversampled ( $53 \%$ versus $47 \%$ ).

\section{Incentives}

Respondents were requested to first complete two parts of incentivized games and then fill out the survey, including the subjective measure of risk aversion and several background questions. ${ }^{14}$ All participants first received instructions about what to expect in general and about the reward structure. Instructions also included examples to get familiar with the experimental setup. The total questionnaire took on average 14 minutes, including possible breaks that people took while online. Except for the general risk question, all decisions in our survey were made incentive compatible and thus had real financial consequences if one was a selected as prize winner. This was clearly communicated.

Incentives are such that participants can earn a maximum of $€ 675$ ( $€ 200$ in Part 1 and $€ 475$ in Part 2) and a minimum of $€ 90$ ( $€ 100$ in Part 1 and $-€ 10$ in Part 2), depending on their choices

\footnotetext{
${ }^{13}$ See Appendix A for the translated letter.

${ }^{14}$ The first part of incentivizes gameswas designed to obtain proxies for overoptimism while the second part aimed at eliciting preferences such as risk and loss aversion. This paper only reports about the second part.
} 
and luck. The luck component consist of three elements. First, decisions involve a random draw whenever a participant selects a risky or ambiguous option. Second, in each of the two parts, only one decision is randomly selected for payment. Such a procedure is quite common in the literature (see e.g. Laury, 2006 and Dohmen et al., 2011) and is according to Azrieli et al. (2012) the only incentive-compatible way to utilize the MPL method. Third, only a random selection of participants are selected as winners and actually paid out. Given a limited budget and the income levels of the participants we chose to pay out substantial (instead of very small) amounts to a few (instead of all) randomly selected participants. ${ }^{15}$ In round 1 we randomly selected two winners from each day's completed participants' files in the first week and one winner per day in the second week. This resulted in 21 prize winners in round 1 in total. In the second round, we paid out five participants. Overall, chances of getting paid out were 1/62 in the first round and 1/196 in the second round. This was unknown to the participants (and ourselves) beforehand.

\section{Draw and payment schedule}

To foster trust, all prize winners as well as all other random draws were performed by a civil-law notary who also monitored a legitimate course of the payouts. The procedure at the notary was as follows. Before the start of the experiment, it was agreed that we would pay out the 15th and 30th participant of each day in the first week and the 15th participant of each day in the second week. The daily rankings were established based on the registered end time of each survey. Furthermore, we also determined a payment schedule prior to the experiment which outlined the two winning choices in Part 1 and Part 2 for each prize winner and whether s/he was lucky when taking the risky option. The most involved part was to settle the ambiguity in our ambiguity aversion measure. Here we took two draws from two urns with 101 numbers (0 until 100). The first draw rendered a benchmark number that corresponded to the percentage of winning (e.g. 88 leads to an $88 \%$ chance of winning). The second draw from the other urn determined if a participant was lucky, which occurred whenever the second number was lower than or equal to the first number. Overall, these series of draws yielded a payment schedule that was accustomed to every choice a prize winner could make. The notary's official statement on the draws (in Dutch) is available upon request.

\section{Default definitions of entrepreneurs, managers and employees}

The qualifying characteristics for inclusion in the entrepreneur sample were: all people who have founded, inherited or taken over a company that they are currently (co-)managing. We also classified participants as 'entrepreneurs' who obtained firm ownership over a company within 5 years after start-up and who are currently its (co-)manager. Individuals qualify for inclusion in the sample of 'managers' if they are employed by an organization that they did not start up themselves and have at least two subordinates for whom they are directly responsible. We also classify project managers as 'managers' in case they have overall responsibility for their projects and at least two direct reporting lines. People belong to the group of 'employees' if they are employed by an organization

\footnotetext{
${ }^{15}$ Laury (2006) finds evidence that the two payment procedures lead to similar results.
} 
and do not belong to the first two groups. ${ }^{16}$

\subsection{Descriptive statistics}

Panel A in Table 1 shows the sample descriptive statistics $(\mathrm{N}=2288)$ of the measures of risk, loss and ambiguity aversion. Panel B reports the correlations between these variables,. For ease of presentation we have reversely coded the survey measure of risk, such that a higher value now implies a stronger aversion to risk. Note, however, that the levels of the different measures in panel A are not directly comparable.

Panel B shows that most of the correlations between the measures are rather low. The correlation with the highest absolute value is the one between the two measures of risk attitude. The survey-based measure of risk attitude is also correlated significantly with both loss and ambiguity aversion, but to a lower degree. The low correlations between the three experimental measures support the idea that these measures capture distinct behavorial aspects of risk and uncertainty.

\section{$<$ INSERT TABLE 1 HERE $>$}

Table 2 shows the descriptive statistics of some characteristics that are used to define stricter subsamples of (more successful) entrepreneurs and managers. Panel A shows the income distribution of each of the three samples according to the answer categories used in the questionnaire. Entrepreneurs are over-represented in both tails of the income distribution relative to managers, which is a common observation (Hamilton, 2000). We do not observe substantial differences between the average level of the entrepreneurial and managerial incomes, though. Both are higher than the income level of employees. For entrepreneurs and managers, the median income is in the category of $€ 50,001-€ 75,000$.. For employees the median value falls in a lower category, i.e., $€ 25,001-€ 50,000$, which is in line with the modal income of $€ 33,500$ in the Netherlands in 2013. For all groups we will analyze subsamples of above median income earners.

Panel B shows that $82 \%$ of the entrepreneurs in our sample are the founder of their firms, a commonly used stricter definition of entrepreneurs. $14 \%$ of the firms have been acquired through a takeover and in $4 \%$ of the cases, the entrepreneurs have bought themselves into the business they currently (co-)manage within five years after its start-up. For managers we are interested in subsamples of CEOs (17\%) and all managers except those who are responsible for projects rather than people $(82 \%)$.

\footnotetext{
${ }^{16}$ Participants who are both entrepreneurs and managers or employees, and therefore eligible for multiple subsamples, were instructed to select the one generating most of their income. With the exception of 12 participants, these instructions were followed up adequately.
} 


\section{$<$ INSERT TABLE 2 HERE $>$}

Panel C shows that $20 \%$ (38\%) of the entrepreneurs are currently managing and leading young firms in their start-up (survival) phase. Some studies define entrepreneurs exclusively as the owner/managers of start-ups (e.g., Brockhaus, 1980; Busenitz and Barney, 1997), whereas other studies explicitly take them out (Holm et al., 2013). We shall use the same distinctions to test the robustness of our results against using various definitions of the entrepreneur. Panel $\mathrm{C}$ also shows that almost half of the entrepreneur sample consists of incorporated business owners. This enables us to limit the sample of entrepreneurs to incorporated business owners consistent with, for instance, Levine and Rubinstein (2012). The right handside of Panel C shows the age and size distributions of the firms that managers and employees work for. As expected these distributions are similar, but different from the ones of entrepreneurial firms. The latter are younger (see panel C) and smaller (see Panel D). As a robustness check we shall split the sample of managers according to the age and size distribution of their firms. Managers in smaller and younger, i.e., more entrepreneurial firms, may be more similar to entrepreneurs.

Panel D of Table 2 shows the distribution of the number of employees supervised by entrepreneurs and managers. $17 \%$ of the entrepreneurs have zero employees and $43 \%$ have at most one. We also consider a stricter definition of entrepreneurship based on the number of employees they employ (cf. e.g. Tag et al., 2013) and do the same for managers.

Table 3 compares background characteristics of the three subsamples. Entrepreneurs and managers are similar in terms of the most commonly used background characteristics: their age, the percentage of females as well as their experience and educational background. Employees are different in terms of their background characteristics compared to the other two groups: they are somewhat younger (mean age is 41), more likely to be female and they have lower educational degrees on average.

$<$ INSERT TABLE 3 HERE $>$

\section{Results}

\subsection{Main results}

To get a first impression of our main findings, Table 4 and Figure 4 show the means and distributions of the four measures of risk and uncertainty for each of the three groups of interest.

$<$ INSERT TABLE 4 HERE $>$ 
The first column in Table 4 shows that entrepreneurs subjectively assess themselves as less risk averse than managers. Managers, in turn, rate themselves as less risk averse than employees, leading to a significant difference of the coefficients. ${ }^{17}$ Two sample t-tests confirm that the differences between entrepreneurs and employees, entrepreneurs and managers, and managers and employees are all highly significant $(p<0.001$ in all cases). Ranksum and Kolmogorov-Smirnov tests generate the same results.

The second column shows that the experimental measure of risk aversion is not significantly lower for entrepreneurs when compared to managers, although both entrepreneurs and managers are significantly less risk averse than employees. ${ }^{18}$ The rest of the table reveals that the raw differences in terms of loss aversion show a similar pattern: entrepreneurs are least loss averse, followed by managers and employees. Here the difference between entrepreneurs and managers is significant at the $5 \%$ level, whereas the difference between managers and employees is not $(p=0.08) .{ }^{19}$ The last column of Table 4 reveals an unexpected pattern: entrepreneurs and managers, who are equally ambiguity averse, are more ambiguity averse than employees.

The CDF plots in Figure 4 provide further insight into the distributions of each of the measures. Starting with the subjective risk aversion plot on the top left, one can observe that the peak of the distribution of entrepreneurs is shifted to the left relative to the one of managers and employees, thus suggesting that most entrepreneurs have a lower value of risk aversion than managers and employees. As witnessed in Table 4 as well, a slightly different pattern arises in the objective risk aversion measure (top right), where the distributions of entrepreneurs and managers are more similar. Turning to loss aversion (bottom left), we find that the distributions appear graphically more like a mix of the subjective and objective risk aversion measures, with the distributions of entrepreneurs and managers being more distinct again. Finally, the ambiguity aversion distributions of all groups (bottom right) are harder to distinguish. Yet the figure confirms that employees appear slightly less ambiguity averse than the other two groups across the board. Moreover, the graphs also illustrate that the majority of participants $( \pm 30 \%)$ always refrained from the ambiguous option and rather preferred the risky one.

\section{$<$ INSERT FIGURE 4 HERE >}

In Table 5 the output of ordered probit regressions for each of the four behavorial variables is depicted. Control variables such as age, gender, education, experience and income are included.

\footnotetext{
${ }^{17}$ The same results are obtained for the other domains measured, i.e., financial risk and career risk.

${ }^{18}$ In terms of the certainty equivalences per group; we find that the average CE category is equal to $€ 125$ - $€ 150$ for entrepreneurs and managers and equal to $€ 100-€ 125$ for employees. As expected, all average values are below the expected value of $€ 150$. The associated CRRA coefficients (but see Rabin, 2000, for a criticism of this approach) would be approximately $0-0.21$ for entrepreneurs and managers and $0.21-0.37$ for employees, the latter being in line with the lower bound of the study of Holt and Laury (2002) among students.

${ }^{19}$ In terms of loss aversion coefficients per group; we find that the average coefficient is equal to 1.11 for entrepreneurs, 1.18 for managers and 1.23 for employees. For the sake of comparison, this is in the lower part of the interquartile range of Gächter et al. (2010).
} 
Columns ' $a$ ' show the results excluding some arguably endogenous variables, i.e., education, experience and income, whereas columns 'b' include those as explanatory variables (analogous to e.g. Dohmen et al., 2010).

\section{$<$ INSERT TABLE 5 HERE $>$}

Table 5 paints a similar picture as Table 4. The first estimation equation shows that entrepreneurs view themselves as less risk averse than managers (see the Wald test in the last row of the table), whereas both entrepreneurs and managers are less risk averse than employees. These findings are largely consistent with previous studies using survey-based measures of risk aversion. The second set of estimates supports the view arisen from Table 4 that entrepreneurs are making similar decisions as managers when taking risky decisions in an experimental and incentived environment. Although they perceive themselves as more risk-taking than managers, they are thus not really. Again we find that both entrepreneurs and managers are less risk averse than employees with similar background characteristics. The third set of results shows that one behavioral characteristic is unique for entrepreneurs: a lower level of loss aversion than both managers and employees. The fourth and final set of results indicate that the differences between employees on the one hand and entrepreneurs and managers on the other hand in terms of ambiguity aversion disappear when including more controls in the equation. Apparently, entrepreneurs, managers and employees that are comparable in terms of their age, gender, education, income and experience don't show differences in their attitudes towards ambiguity. This result was also obtained by Holm et al. (2013).

The control variables also have different associations with the survey-based measure of risk than with all three experimental measures. Older people claim to be less willing to take risks in general (consistent with Dohmen et al. 2011) but none of the three experimental measures is significantly associated with age. Females are less risk taking according to the survey-based measure (also consistent with Dohmen et al., 2011) but the choice based measures are no different for females than for males. The latter result is largely consistent with the conclusions from a recent meta-analysis about gender differences in risk attitudes elicited by this type of games (Filippin and Crosetto, 2014). ${ }^{20}$

In an effort to reconcile the abovementioned findings, we have also directly compared the subjective and objective measures of risk and ambiguity. Table 6 shows that the subjective assessments of respondents' risk attitudes are not only correlated with the experimental risk measure, but also with loss and ambiguity aversion. ${ }^{21}$ All three coefficients in the ordered probit regression on risk

\footnotetext{
${ }^{20}$ Also for education we find the expected negative effect using the survey-based Dohmen measure of risk appetite, (cf. Harrison et al., 2007), but no significant effect when using any of the experimental measures. People with higher incomes view themselves as less risk-averse (by comparison; in Dohmen et al., 2010 the effect of household income is the same but just insignificant). Interestingly, higher income people are less loss averse according to the experimental measure but not less risk or ambiguity averse. These results are not included in the table.

${ }^{21}$ See also Ding et al. (2010) and Willebrands et al. (2012) for other work on subjective vis-à-vis objective risk measures.
} 
attitude are highly significant and have the expected positive sign. The measure of risk has the highest association with the self-assessed risk attitude, but both loss and ambiguity aversion play a significant part too in the explanation of the self-assessed value. The result is the same both without (column 1) and with (column 2) controls for entrepreneur and managers. In column 3 all three coefficients are calculated separately for managers and entrepreneurs by including interactions with these dummy indicators. The benchmark is the subsample of employees. The associations between the subjective assessment of risk and the objective measures are similar for managers and employees; the coefficients of the interacted variables with 'manager' all lack statistical significance. However, for entrepreneurs there are some notable differences. The association with risk aversion is lower than for the rest of the sample, although the relationship remains significantly different from zero. The latter does not hold for ambiguity aversion, though; here a similar test shows that for entrepreneurs we cannot reject the null hypothesis that ambiguity aversion does not impact willingness to take risks. All in all, the results in column 3 indicate that entrepreneurs base their self-assessment of risk appetite on their loss aversion, more than on their risk or ambiguity aversion. For managers and employees this is not the case. A low level of loss aversion is thus a distinguishing feature of entrepreneurs and they associate this with having a higher risk appetite than others.

\section{$<$ INSERT TABLE 6 HERE $>$}

Overall we draw two conclusions from this analysis: (1) subjective assessments of risk attitude proxy for more than just risk aversion and (2) there is a greater divergence between subjective assessments of risk attitude and behavioral observations for entrepreneurs than for others. Entrepreneurs associate loss aversion with risk aversion.

\subsection{Robustness Checks}

In this section we will first test to what extent the results remain the same when using stricter definitions of entrepreneurs and managers. ${ }^{22}$ Table 7 displays the main result of Table 5, using various alternative definitions. Thus, each coefficient is obtained in a separate regression (see Table 5 for the specifics of these regressions).

\section{$<$ INSERT TABLE 7 HERE $>$}

\footnotetext{
${ }^{22}$ Table 2 shows that the samples of entrepreneurs, managers and, to a lesser extent, employees are suitable for the creation of subsamples based on stricter, alternative, also commonly used defitions of entrepreneurs, managers and employees.
} 
For entrepreneurs we use a set of stricter definitions in congruence with the literature mentioned earlier in Section 3. We use the subsets of: (i) entrepreneurs with an incorporated firm, thereby mainly excluding the own-account self-employed, (ii) entrepreneurs with an above median number of fulltime equivalent employees in their company, (iii) entrepreneurs with above median incomes, (iv) entrepreneurs that have founded their business, instead of obtaining it through takeover or buy-in, (v) entrepreneurs in the survival phase (firm age $\leq 5$ years) and (vi) entrepreneurs past their survival phase (firm age $>5$ years) ${ }^{23}$ Panel A of Table 7 shows the results of confronting the data with these alternative definitions of the entrepreneur. For managers and employees we employ the original samples. The last line in Panel A shows the result of Table 5 again.

The panel shows a clear pattern consistent with the findings in Table 5. Whatever definition of the entrepreneur is used, they assess themselves as more risk taking than both managers and entrepreneurs. Using objective measures of risk and uncertainty, the data show again that entrepreneurs and managers are equally risk averse, but less so than employees. The only notable and significant difference with the benchmark appears when limiting the sample to incorporated entrepreneurs. They are significantly less risk averse than both managers and employees. ${ }^{24}$ Loss aversion is the one behavorial feature that distinguishes entrepreneurs from managers. The results in Table 5 turn out to be robust against using various stricter definitions of (successful) entrepreneurship.

Panel B of Table 7 shows the results when varying the definition of a manager while keeping the baseline samples of entrepreneurs and employees. Again we find that the main results remain, irrespective of the definition used. We restrict the sample to: (vii) CEOs or general managers (as opposed to project managers), (viii) CEOs exclusively, (ix) managers with more than the medium number of direct reports, (x) managers with bove median managerial income, and (xi) managers in firms that are older than 15 years. The stricter definitions used do not only restrict the sample to more successful managers but also, in some cases, to managers that can reasonably be expected to be more different from entrepreneurs than average, such as the ones employed in older firms. Again, the last line of the panel shows the result for managers copied from Table 5, i.e., the benchmark.

Panel C finally tests some of the alternative definitions against each other. Whether we compare entrepreneurs of incorporated firms (i) with CEOs (viii), or whether we compare entrepreneurs (ii) and managers (ix) with larger spans of control, or higher than median incomes ((iii) versus (x)), the results remain very similar to the main findings according to the Wald statistics in each of these cases. $^{25}$

Another robustness check is based on the idea that many people are belonging to one of the

\footnotetext{
${ }^{23}$ We also analyzed subsamples of entrepreneurs based on their share ownership (for instance a minimum of $30 \%$ or $50 \%$ ), leaving the main result unchanged.

${ }^{24}$ To support this finding we ran similar regressions using only the sample of entrepreneurs. The regression outputs confirm that incorporated as well as above median income earning entrepreneurs are significantly less risk averse than other entrepreneurs at the $10 \%$ level.

${ }^{25}$ We also employed a stricter definition of employees by limiting that subsample to above median income earners (effectively cutting off the lowest category of the $26 \%$ of wage employees earning incomes lower then 25,000 euro's, see Table 2). Again the results were the same.
} 
groups at the time of measurement, but may have been part of another group in the past. In other words, the distinction between the three groups in terms of typology is not black-white. Possibly, the differences between the 'pure' groups are larger when taking into account that some individuals belong to 'gray' areas. Appendix B reports the results from analyses that take this into account. Appendix Table B1 shows that $71 \%$ of the entrepreneurs in the sample have been managers in the past and $9 \%$ is currently wage employee or manager besides being a business owner. Moreover 17 (10)\% of the managers (employees) is also an entrepreneur on the side, whereas 12 (9)\% of the managers (employees) have been so in the past. Apparently, people move out of and especially into entrepreneurship in the course of their professional lives. Appendix Table B2 shows that the effects found in Table 5 (and 7) do not change when accounting for past and current positions in the other groups. The coefficients of the controls that distinguish the gray groups from the 'pure' groups have the expected signs (diminishing the main effect), but they are not significant.

\section{Conclusion}

Common wisdom and economic theory alike portray entrepreneurs as a truly distinct breed. Most notably, the stereotype is that entrepreneurs, as business owning residual claimants, are more willing and better able to cope with risk and uncertainty. Existing empirical studies that ask entrepreneurs and non-entrepreneurs to subjectively self-assess their attitude towards risk and uncertainty, indeed by and large confirm this conventional wisdom; entrepreneurs take themselves as being more willing to take risks than non-entrepreneurs are. Other studies that employ incentivized choice-based measures of risk aversion, however, find little differences between entrepreneurs and the comparison group employed. These opposing findings immediately raise the question of whether entrepreneurs' more positive attitude towards risk is merely a common (mis)perception, or whether they have truly distinct preferences.

In this paper we report the results from a lab-in-the-field experiment that sheds light on this matter. Our experiment has a number of distinguishing features. First of all, it is relatively large in size with 2288 respondents overall, including 910 entrepreneurs. Second, we compare entrepreneurs with two well-defined control groups, viz. managers and employees. Entrepreneurs and managers are very similar in terms of background characteristics and arguably also in terms of the professional decisions and tasks they face, including managing the employees they direct. Yet as residual claimants only entrepreneurs directly feel the financial consequences of the decisions they take. Especially this difference is thought to draw people with distinct risk preferences into entrepreneurship. Differences between entrepreneurs and employees (both in terms of background characteristics and professional activities) are more pronounced. Third, we collect a large variety of background characteristics and measures of individual 'success'. This allows us to zoom in on particular subsamples, using more stringent definitions of both entrepreneurs and managers based on being 'more succussful'. Last, we include both a subjective, survey-based measure of risk attitude, as well as incentivized, 
choice-based measures of risk related preferences. This allows us to compare subjective perceptions of risk attitude with objectives measures based on actual choices with true financial consequences. Besides a standard measure of risk aversion, we also include measures of loss aversion and ambiguity aversion.

In line with previous studies and conventional wisdom, the entrepreneurs in our sample on average perceive themselves as being more risk tolerant than the other respondents. This not only holds with respect to the employees in our sample, but also in regard to the more comparable control group of managers. Based on the incentived choice-based measure of risk aversion, however, entrepreneurs are equally risk averse as managers (with employees being significantly more risk averse). The different perceptions of entrepreneurs and managers thus cannot be explained by differences in risk aversion as narrowly defined by economists. Rather, our results show that these different perceptions mainly result from significant differences in attitudes towards losses; managers are significantly more loss averse than entrepreneurs are (with employees in turn being more loss averse than managers, although not significantly). The three groups do not differ in terms of ambiguity aversion. These findings are largely independent of the definition of who is an entrepreneur and who is a manager. If anything, limiting the sample to more successful entrepreneurs somewhat strengthens our results.

When self-assessing their 'willingness to take risks in general' on a 0 to 10 scale, respondents appear to have a broader notion of 'risk' in mind than the narrow risk aversion measure of economists. Besides risk aversion, also ambiguity and loss aversion play an important role in shaping individual perceptions. For the perceived difference between entrepreneurs and managers, loss aversion turns out to be key. Managers are on average more inclined to avoid losses than entrepreneurs are, leading to a lower self-assessed willingness to take risks.

Overall we conclude that, when it comes to attitudes towards risk and uncertainty, entrepreneurs are different but in a rather subtle way. The Merriam-Webster dictionary website defines an entrepreneur as "...a person who starts a business and is willing to risk loss in order to make money". In terms of their willingness to risk losses, entrepreneurs indeed appear to be distinct.

\section{References}

Azrieli, Y., C.P. Chambers, P.J. Healy. 2012. Incentives in experiments: a theoretical analysis. Ohio State University Working Paper.

Beauchamp, J., D. Cesarini, M. Johannesson. 2012. The psychometric properties of measures of economic risk preferences. mimeo .

Begley, T. M. 1995. Using founder status, age of firm, and company growth rate as the basis for distinguishing entrepreneurs from managers of small businesses. Journal of Business Venturing 10 pp. 249-263.

Berger, A. N., G. F. Udell. 1998. The economics of small business finance: The roles of private equity and debt markets in the financial growth cycle. Journal of Banking and Finance 22 pp. 613-673. 
Block, J., P. Koellinger. 2009. I can't get no satisfaction - necessity entrepreneurship and procedural utility. Kyklos 62(2) pp. 191-209.

Bonin, H., T. Dohmen, A. Falk, D. Huffman, U. Sunde. 2007. Cross-sectional earnings risk and occupational sorting: The role of risk attitudes. Labour Economics 14(6) pp. 926-937.

Borghans, L., A. Duckworth, J. Heckman, B. Ter Weel. 2008. The economics and psychology of personality traits. Journal of Human Resources 43(4) pp. 972-1059.

Brachert, M., W. Hyll. 2014. On the stability of preferences: Repercussions of entrepreneurship on risk attitudes. SOEPpaper No. 667 .

Brockhaus, R.H. 1980. Risk taking propensity of entrepreneurs. The Academy of Management Journal 23 pp. 509-520.

Burmeister-Lamp, K., M. Levesque, C. Schade. 2012. Are entrepreneurs influenced by risk attitude, regulatory focus or both? an experiment on entrepreneurs' time allocation. Journal of Business Venturing 27(4) pp. 456-476.

Busenitz, L.W., J.B. Barney. 1997. Differences between entrepreneurs and managers in large organizations: biases and heuristics in strategic decision-making. Journal of Business Venturing 12 pp. 9-30.

Caird, S. 1991. The enterprise tendency of occupational groups. International Small Business Journal 9(4) pp. 75-91.

Caliendo, M., F. Fossen, A. Kritikos. 2009. Risk attitudes of nascent entrepreneurs: New evidence from an experimentally-validated survey. Small Business Economics 32(2) pp. 153-167.

Caliendo, M., F. Fossen, A. Kritikos. 2010. The impact of risk attitudes on entrepreneurial survival. Journal of Economic Behavior \& Organization 76(1) pp. 45-63.

Cantillon, R. 1755. Essai Sur la Nature Général. London Macmillan.

Cramer, J. S., J. Hartog, N. Jonker, C. M. Van Praag. 2002. Low risk aversion encourages the choice for entrepreneurship: an empirical test of a truism. Journal of Economic Behavior \& Organization 48(1) pp. 29-36.

DeMartino, R., R. Barbato. 2003. Differences between women and men mba entrepreneurs: exploring family flexibility and wealth creation as career motivators. Journal of Business Venturing 18(6) pp. 815-832.

Ding, X., J. Hartog, Y. Sun. 2010. Can we measure individual risk attitudes in a survey? IZA discussion paper No. 4807 .

Djankov, S., Y. Qian, G. Roland, E. Zhuravskaya. 2006. Who are china's entrepreneurs? American Economic Review Papers and Proceedings 96(2) pp. 348-352.

Djankov, S., Y. Qian, G. Roland, E. Zhuravskaya. 2007. What makes a successful entrepreneur? evidence from brazil. Working Paper 0104, Center for Economic and Financial Research .

Dohmen, T., A. Falk, D. Huffman, U. Sunde. 2010. Are risk aversion and impatience related to cognitive ability? American Economic Review 100(3) pp. 1238-1260.

Dohmen, T., A. Falk, D. Huffman, U. Sunde, J. Schupp, G. G. Wagner. 2007. The measurement and stability of risk attitudes. mimeo .

Dohmen, T., A. Falk, D. Huffman, U. Sunde, J. Schupp, G. G. Wagner. 2011. Individual risk attitudes: Measurement, determinants and behavioral consequences. Journal of the European Economic Association 9(3) pp. 522-550.

Ellsberg, D. 1961. Risk, ambiguity, and the savage axioms. The Quarterly Journal of Economics 75 pp. 643-669.

Elston, J.A., Rutström E.E. Harrison, G.W. 2006. Experimental economics, entrepreneurs and the entry decision. Working Paper No. 6, University of Central Florida .

Evans, D.S., B. Jovanovic. 1989. An estimated model of entrepreneurial choice under liquidity constraints. Journal of Political Economy 97 pp. 808-827. 
Fairlie, R.W., H.A. Krashinsky. 2012. Liquidity constraints, household wealth, and entrepreneurship revisited. Review of Income and Wealth, International Association for Research in Income and Wealth, 58(2) pp. 279-306.

Fehr, E., L. Goette. 2007. Do workers work more if wages are high? evidence from a randomized field experiment. The American Economic Review 97(1) pp. 298-317.

Filippin, A., P. Crosetto. 2014. A reconsideration of gender differences in risk attitudes. IZA discussion paper No. 8184 .

Fouarge, D., B. Kriechel, T. Dohmen. 2014. Occupational sorting of school graduates: The role of economic preferences. IZA working paper No. 8355 .

Fox, C.R., A. Tversky. 1995. Ambiguity aversion and comparative ignorance. The Quarterly Journal of Economics 110(3) pp. 585-603.

Gächter, S., E.J. Johnson, A. Herrmann. 2010. Individual-level loss aversion in riskless and risky choices. CeDEx discussion paper series, No. 2010-20 .

Gentry, W.M., R.G. Hubbard. 2004. Entrepreneurship and household saving. Advances in Economic Analysis and Policy 4(1) article 8.

Gneezy, U., A. Pietrasz. 2014. When half of the men are more competitive than all women. ASSA discussion paper, Philadelphia .

Graham, J.R., C.R. Harvey, M. Puri. 2013. Managerial attitudes and corporate actions. Journal of Financial Economics 109 pp. 103-121.

Hamilton, B.H. 2000. Does entrepreneurship pay? an empirical analysis of the returns to selfemployment. Journal of Political Economy 108(3) pp. 604-631.

Harrison, G.W., M.I. Lau, E. Rutström. 2007. Estimating risk attitudes in denmark: A field experiment. The Scandinavian Journal of Economics 109(2) pp. 341-368.

Heaton, J. C., D. J. Lucas. 2004. Capital structure: Hurdle rates and portfolio choice interactions in an entrepreneurial firm. Working Paper, Northwestern University .

Heaton, J.C., D.J. Lucas. 2000. Portfolio choice in the presence of background risk. Economic Journal 110(460) pp. 1-26.

Henrekson, M., T. Sanandaji. 2014. Small business activity does not measure entrepreneurship. Proceedings of the National Academy of Sciences pp. 1760-1765.

Holm, H.J., S. Opper, V. Nee. 2013. Entrepreneurs under uncertainty: An economic experiment in china. Management Science 59(7) pp. 1671-1687.

Holt, C.A., S.K. Laury. 2002. Risk aversion and incentive effects. The American Economic Review 92(5) pp. 1644-1655.

Holtz-Eakin, D., D Joulfaian, H.S. Rosen. 1994a. Entrepreneurial decisions and liquidity constraints. RAND Journal of Economics 25 334-347.

Holtz-Eakin, D., D Joulfaian, H.S. Rosen. 1994b. Sticking it out: entrepreneurial survival and liquidity constraints. Journal of Political Economy 102 53-75.

Hull, D., J. Bosley, G. Udell. 1980. Renewing the hunt for heffalump: Identifying potential entrepreneurs by personality characteristics. Journal of Small Business Management 18(1) pp. $11-18$.

Hvide, H.K., J. Møen. 2010. Lean and hungry or fat and content? entrepreneurs' wealth and start-up performance. Management Science 56(8) pp. 1242-1258.

Kahneman, D., J.L. Knetsch, R.H. Thaler. 1990. Experimental tests of the endowment effect and the coase theorem. Journal of Political Economy 98(6) pp. 1325-1348.

Kahneman, D., D. Lovallo. 1993. Timid choices and bold forecasts: A cognitive perspective on risk taking. Management Science 39(1) pp. 17-31.

Kahneman, D., A. Tversky. 1979. Prospect theory: An analysis of decision under risk. Econometrica 47 pp. 263-291. 
Kahneman, D., A. Tversky. 1984. Choices, values, and frames. American Psychologist 39(4) pp. $341-350$.

Kihlstrom, R.E., J.-J. Laffont. 1979. A general equilibrium entrepreneurial theory of firm formation based on risk aversion. Journal of Political Economy 87(4) pp. 719-748.

Kirzner, I. 1973. Competition and Entrepreneurship. University of Chicago Press.

Knight, F.H. 1921. Risk, uncertainty, and profit. Houghton Mifflin Company (Boston).

Koh, H. C. 1996. Testing hypotheses of entrepreneurial characteristics: a study of hong kong mba students. Journal of Managerial Psychology 11 pp. 12-25.

Laury, S. L. 2006. Pay one or pay all: Random selection of one choice for payment. Andrew Young School of Policy Studies Research Paper Series No. 06-13.

Levine, R., Y. Rubinstein. 2012. Does entrepreneurship pay? the michael bloombergs, the hot dog vendors, and the returns to self-employment. mimeo .

Lindquist, M., J. Sol, C.M. van Praag. 2013. Why do entrepreneurial parents have entrepreneurial children? Journal of Labor Economics (forthcoming).

Lonnqvist, J.E., M. Verkasalo, G. Walkowitz, P.C. Wichardt. 2011. Measuring individual risk attitudes in the lab: task or ask? an empirical comparison. mimeo .

Macko, A., T. Tyszka. 2009. Entrepreneurship and risk taking. Applied Psychology 58(3) pp. 469-487.

Marshall, A. 1930. Principles of Economics. London Macmillan.

Miner, J.B., N.S. Raju. 2004. Risk propensity differences between managers and entrepreneurs and between low- and high-growth entrepreneurs: A reply in a more conservative vein. Journal of Applied Psychology 89(1) pp. 3-13.

Moskowitz, T.J., A. Vissing-Jorgensen. 2002. The returns to entrepreneurial investment: A private equity premium puzzle? American Economic Review 92(4) pp. 745-778.

Parker, S.C. 2009. The Economics of Entrepreneurship. University Press, Cambridge.

Petersen, M. A., R. G. Rajan. 1994. The benefits of lending relationships: Evidence from small business data. Journal of Finance 49 pp. 3-37.

Rabin, M. 2000. Risk aversion and expected-utility theory: A calibration theorem. Econometrica 68 pp. $1281-1292$.

Sahm, C. 2012. How much does risk tolerance change? Quarterly Journal of Finance 2(4).

Sandri, S., C. Schade, O. Musshoff, M. Odening. 2010. Holding on for too long? an experimental study on inertia in entrepreneurs' and non-entrepreneurs' disinvestment choices. Journal of Economic Behavior \& Organization 76(1) pp. 30-44.

Sarasvathy, D.K., H. Simon, L. Lave. 1998. Perceiving and managing business risks: Differences between entrepreneurs and bankers. Journal of Economic Behavior \& Organization 33(2) pp. 207-222.

Say, J.-B. 1803. A Treatise on Political Economy or the Production, Distribution and Consumption of Wealth. A.M. Kelley Publishers, New York.

Schere, J.L. 1982. Tolerance of ambiguity as discriminating variable between entrepreneurs and managers. Academy of Management Best Paper Proceedings 42 pp. 404-408.

Schmalz, M.C., D.A. Sraer, D. Thesmar. 2013. Household collateral and entrepreneurship. NBER Working Paper No. w19680.

Stewart Jr., W. H., P. L. Roth. 2001. Risk propensity differences between entrepreneurs and managers: a meta-analytic review. Journal of Applied Psychology 86(1) pp. 145-153.

Stewart Jr., W. H., W.E. Watson, J.C. Carland, J.W. Carland. 1999. A proclivity for entrepreneurship: A comparison of entrepreneurs, small business owners, and cooperate managers. Journal of Business Venturing 14(2) pp. 189-214.

Swalm, R.O. 1966. Utility theory (insights into risk taking). Harvard Business Review 44(6) pp. 
$123-136$.

Tag, J., T. Astebro, P. Thompson. 2013. Hierarchies, the small firm effect, and entrepreneurship: Evidence from swedish microdata. IFN Working Paper No. 954.

Tversky, A., D. Kahneman. 1992. Advances in prospect theory: Cumulative representation of uncertainty. Journal of Risk and Uncertainty 5(4) pp. 297-323.

Uusitalo, R. 2001. Homo entreprenaurus? Applied Economics 33(13) pp. 1631-1638.

Van Praag, C. M., J. S. Cramer. 2001. The roots of entrepreneurship and labour demand: individual ability and low risk aversion. Economica 68 pp. 45-62.

Van Praag, C.M. 1999. Some classic views on entrepreneurship. The Economist 147(3) pp. 311-335.

Wakker, P. P. 2005. Formalizing reference dependence and initial wealth in rabin's calibration theorem. Working Paper, Erasmus University Rotterdam .

Wakker, P. P. 2010. Prospect theory: For risk and ambiguity. Cambridge University Press, Cambridge.

Willebrands, D., J. Lammers, J. Hartog. 2012. A successful businessman is not a gambler; risk attitude and business performance among small enterprises in nigeria. Journal of Economic Psychology 22(2) pp. 342-354. 


\section{Tables}

Table 1: Descriptive Statistics of the Measures of Risk, Loss, and Ambiguity Aversion

\begin{tabular}{|c|c|c|c|c|c|c|}
\hline Panel A: Means & Observations & Mean & St. dev. & Minimum & Maximum & \\
\hline \multicolumn{7}{|l|}{ Risk Aversion } \\
\hline - Survey measure ${ }^{1}$ & 2288 & 3.67 & 1.79 & 0 & 10 & \\
\hline - Experimental measure & 2288 & 5.38 & 2.76 & 0 & 10 & \\
\hline Loss Aversion & 2288 & 5.05 & 2.65 & 0 & 10 & \\
\hline Ambiguity Aversion & 2288 & 5.74 & 3.64 & 0 & 10 & \\
\hline Panel B: Correlations & Risk Aversion & Risk & Aversion & Loss Aversion & Ambiguit & y Aversion \\
\hline \multicolumn{7}{|l|}{ Survey $(S)$ or } \\
\hline Experimental (E) & $(\mathrm{S})$ & & $(\mathrm{E})$ & $(\mathrm{E})$ & & E) \\
\hline \multicolumn{7}{|l|}{ Risk Aversion } \\
\hline - Survey measure ${ }^{1}$ & - & & & & & \\
\hline - Experimental measure & 0.17 & & - & & & \\
\hline Loss Aversion & 0.12 & & 0.05 & - & & \\
\hline Ambiguity Aversion & 0.05 & & 0.05 & -0.01 & & - \\
\hline
\end{tabular}

${ }^{1}$ Reverse coded measure of "Willingness to take risks"

This table shows the descriptive statistics of the two measures of risk aversion, loss aversion and ambiguity aversion. The survey measure of risk aversion is a reverse coded measure of the original self-reported willingness to take risks. In the reverse coded survey measure, 0 corresponds to the highest level of wilingness to take risks and 10 the lowest. The experimental measure of risk aversion is equal to the number of safe decisions made in the 10 decisions, and ranges from 0 to 10 . Hence, more risk averse participants have a higher score. Similarly, loss aversion measures the number of safe decisions made in the loss aversion multiple price list (range: 0-10). Ambiguity aversion (range: $0-10$ ) is equal to a participant's number of non-ambiguous decisions in the multiple price list for ambiguity. The higher the value, the more ambiguity averse is the person. 
Table 2: Descriptives of Variables to Define Sample Splits within Entrepreneurs, Managers, and Employees

\begin{tabular}{|c|c|c|c|c|}
\hline & $\begin{array}{l}\text { Entrepreneurs } \\
\quad(\mathrm{N}=910)\end{array}$ & & $\begin{array}{l}\text { Managers } \\
(\mathrm{N}=397)\end{array}$ & $\begin{array}{c}\text { Employees } \\
(\mathrm{N}=981)\end{array}$ \\
\hline \multicolumn{5}{|l|}{ Panel A: Income } \\
\hline$<€ 25,000$ & $23 \%$ & $<€ 25,000$ & $2 \%$ & $26 \%$ \\
\hline$€ 25,001-€ 50,000$ & $20 \%$ & $€ 25,001-€ 50,000$ & $17 \%$ & $58 \%$ \\
\hline$€ 50,001-€ 75,000$ & $19 \%$ & $€ 50,001-€ 75,000$ & $34 \%$ & $12 \%$ \\
\hline$€ 75,001-€ 125,000$ & $20 \%$ & $€ 75,001-€ 125,000$ & $36 \%$ & $3 \%$ \\
\hline$€ 125,001-€ 200,000$ & $11 \%$ & $€ 125,001-€ 200,000$ & $8 \%$ & $1 \%$ \\
\hline$€ 200,001-€ 300,000$ & $4 \%$ & $€ 200,001-€ 300,000$ & $2 \%$ & $0 \%$ \\
\hline$€ 300,001-€ 400,000$ & $1 \%$ & $€ 300,001-€ 400,000$ & $0 \%$ & $0 \%$ \\
\hline$>€ 400,000$ & $2 \%$ & $>€ 400,000$ & $1 \%$ & $0 \%$ \\
\hline
\end{tabular}

Panel B: Entrepreneur/Manager characteristics

\begin{tabular}{lclcc} 
Founder & $82 \%$ & CEO & $17 \%$ & - \\
Business taken over & $14 \%$ & General Manager & $65 \%$ & - \\
Joined the firm within 5 yrs & $4 \%$ & Project Manager & $18 \%$ & - \\
& & & \\
\hline \\
Panel C: Firm characteristics & & & & \\
& & & $5 \%$ & $6 \%$ \\
Start-up phase (0-3 yrs) & $20 \%$ & Firm age $\leq 5$ yrs & $50 \%$ & $55 \%$ \\
Survival phase (0-5 yrs) & $38 \%$ & Firm age $6-50$ yrs & $45 \%$ & $39 \%$ \\
& & Firm age $>50$ yrs & $13 \%$ & $19 \%$ \\
Incorporated & $49 \%$ & Firm size $\leq 25 \mathrm{FTE}$ & $53 \%$ & $50 \%$ \\
Sole propriotership & $38 \%$ & Firm size 26 - 1000 FTE & $34 \%$ & $31 \%$ \\
Other & $13 \%$ & Firm size > $1000 \mathrm{FTE}$ & &
\end{tabular}

Panel D: Management level

No. of FTE in own firm:

Direct reports:

$\begin{array}{lllcl}0 & 17 \% & 2-5 & 45 \% & - \\ 1 & 26 \% & 6-10 & 30 \% & - \\ 2-5 & 25 \% & 11-25 & 19 \% & - \\ 6-10 & 10 \% & 26-50 & 4 \% & - \\ 11-25 & 11 \% & \text { More than } 50 & 2 \% & - \\ 26-50 & 5 \% & & \\ 51-100 & 4 \% & & \\ 101-500 & 1 \% & & \\ \text { More than } 500 & 1 \% & & \end{array}$


Table 3: Background Characteristics of Entrepreneurs, Managers, and Employees

\begin{tabular}{lccc}
\hline & Entrepreneurs & Managers & Employees \\
\hline Age & & & \\
Female (dummy) & $47.36^{\mathrm{a}}$ & $46.45^{\mathrm{c}}$ & $41.24^{\mathrm{a}, \mathrm{c}}$ \\
Education (highest degree): & $0.25^{\mathrm{a}}$ & $0.28^{\mathrm{c}}$ & $0.53^{\mathrm{a}, \mathrm{c}}$ \\
- High School & $\mathrm{d}$ & $\mathrm{f}$ & $\mathrm{d}, \mathrm{f}$ \\
- Lower intermediate vocational degree & $4 \%$ & $2 \%$ & $3 \%$ \\
- College education & $12 \%$ & $41 \%$ & $34 \%$ \\
- University education & $46 \%$ & $45 \%$ & $42 \%$ \\
& $38 \%$ & & $21 \%$ \\
Number of observations & & 397 & 981 \\
\end{tabular}

a) Significant difference between entrepreneurs and employees at the $5 \%$ level (two-sample t-test)

b) Significant difference between entrepreneurs and managers at the $5 \%$ level (two-sample t-test)

c) Significant difference between managers and employees at the $5 \%$ level (two-sample t-test)

d) Significant difference between entrepreneurs and employees at the $5 \%$ level (Kolmogorov-Smirnov test)

e) Significant difference between entrepreneurs and managers at the $5 \%$ level (Kolmogorov-Smirnov test)

f) Significant difference between managers and employees at the $5 \%$ level (Kolmogorov-Smirnov test) 
Table 4: Raw Differences in Risk, Loss, and Ambiguity Aversion of Entrepreneurs, Managers and Employees

\begin{tabular}{lllll}
\hline & $\begin{array}{l}\text { Risk } \\
\text { Aversion }\end{array}$ & $\begin{array}{l}\text { Risk } \\
\text { Aversion }\end{array}$ & $\begin{array}{l}\text { Loss } \\
\text { Aversion }\end{array}$ & $\begin{array}{l}\text { Ambiguity } \\
\text { Aversion }\end{array}$ \\
$\begin{array}{llll}\text { Survey (S) or } \\
\text { Experimental (E) }\end{array}$ & $(\mathrm{S})$ & $(\mathrm{E})$ & $(\mathrm{E})$ & $(\mathrm{E})$ \\
\hline & & & & \\
Entrepreneurs & $3.10^{\mathrm{a}, \mathrm{b}}$ & $5.03^{\mathrm{a}}$ & $4.77^{\mathrm{a}, \mathrm{b}}$ & $5.88^{\mathrm{a}}$ \\
Managers & $3.69^{\mathrm{b}, \mathrm{c}}$ & $5.17^{\mathrm{c}}$ & $5.08^{\mathrm{b}}$ & $5.90^{\mathrm{c}}$ \\
Employees & $4.20^{\mathrm{a}, \mathrm{c}}$ & $5.78^{\mathrm{a}, \mathrm{c}}$ & $5.29^{\mathrm{a}}$ & $5.54^{\mathrm{a}, \mathrm{c}}$ \\
& & & & \\
\hline
\end{tabular}

a) Significant difference between entrepreneurs and employees at the $5 \%$ level (two-sample t-test)

b) Significant difference between entrepreneurs and managers at the $5 \%$ level (two-sample t-test)

c) Significant difference between managers and employees at the $5 \%$ level (two-sample t-test)

See the note below Table 1 for the definitions of the variables. 
Table 5: Risk -, Loss - , and Ambiguity Aversion of Entrepreneurs, Managers and Employees

\begin{tabular}{|c|c|c|c|c|c|c|c|c|}
\hline \multirow{3}{*}{ Dep. variable: } & (1a) & (1b) & $(2 \mathrm{a})$ & $(2 \mathrm{~b})$ & (3a) & $(3 \mathrm{~b})$ & (4a) & (4b) \\
\hline & Risk & Risk & Risk & Risk & Loss & Loss & Ambiguity & Ambiguity \\
\hline & Aversion & Aversion & Aversion & Aversion & Aversion & Aversion & Aversion & Aversion \\
\hline \multicolumn{9}{|l|}{ Survey (S) or } \\
\hline Experimental (E) & (S) & (S) & $(\mathrm{E})$ & (E) & (E) & $(\mathrm{E})$ & (E) & (E) \\
\hline \multirow[t]{2}{*}{ Entrepreneur } & $-0.655^{* * *}$ & $-0.650^{* * *}$ & $-0.261^{* * *}$ & $-0.282^{* * *}$ & $-0.200^{* * *}$ & $-0.207^{* * *}$ & $0.104^{* *}$ & 0.0198 \\
\hline & {$[-12.43]$} & {$[-9.23]$} & {$[-5.05]$} & {$[-4.03]$} & {$[-3.89]$} & {$[-3.06]$} & [1.99] & {$[0.29]$} \\
\hline \multirow[t]{2}{*}{ Manager } & $-0.256^{* * *}$ & $-0.203^{* * *}$ & $-0.203^{* * *}$ & $-0.254^{* * *}$ & -0.0929 & -0.0176 & $0.120^{*}$ & 0.0484 \\
\hline & {$[4.23]$} & {$[-2.63]$} & {$[-3.32]$} & {$[-3.29]$} & {$[-1.52]$} & {$[-0.23]$} & [1.88] & {$[0.59]$} \\
\hline \multirow[t]{2}{*}{ Age } & $0.0299^{* *}$ & $0.0368^{* *}$ & -0.0206 & $-0.0269^{*}$ & -0.0128 & -0.00815 & 0.00616 & 0.0102 \\
\hline & {$[2.20]$} & {$[2.28]$} & {$[-1.51]$} & {$[-1.68]$} & {$[-0.98]$} & {$[-0.54]$} & {$[0.47]$} & {$[0.69]$} \\
\hline \multirow[t]{2}{*}{ Age squared } & -0.000237 & 0.000275 & 0.000246 & $0.000320^{*}$ & 0.000154 & 0.000117 & -0.000112 & -0.000153 \\
\hline & {$[-1.57]$} & {$[1.59]$} & {$[1.60]$} & [1.81] & [1.03] & {$[0.69]$} & {$[-0.76]$} & {$[-0.95]$} \\
\hline \multirow[t]{2}{*}{ Female } & $0.234^{* * *}$ & $0.134^{* *}$ & 0.0311 & -0.00121 & 0.0612 & 0.0365 & -0.00155 & -0.0113 \\
\hline & {$[4.98]$} & {$[2.49]$} & {$[0.66]$} & {$[-0.02]$} & {$[1.31]$} & {$[0.66]$} & {$[-0.03]$} & {$[-0.21]$} \\
\hline Controls for & NO & YES & NO & YES & NO & YES & NO & YES \\
\hline$N$ & 2288 & 1805 & 2288 & 1805 & 2288 & 1805 & 2288 & 1805 \\
\hline Log lik. & -4235.2 & -3307.9 & -5055.4 & -3956.6 & -4920.8 & -3848.6 & -4919.7 & -3826.6 \\
\hline $\mathrm{ENT}=\mathrm{MAN}^{1}$ & $<0.001^{* * *}$ & $<0.001^{* * *}$ & 0.31 & 0.60 & $0.06^{*}$ & $<0.01^{* * *}$ & 0.80 & 0.36 \\
\hline
\end{tabular}

1) This row reports the p-values of Wald tests on $\beta$ (ENTREPRENEUR) $=\beta$ (MANAGER).

Most variables have been defined earlier. The categorical variables 'education' and 'income' have been summarized into one variable instead of using a set of dummies. the education variable takes on the value 0 if the highest attained level is high school or lower, 1 if secondary education is obtained at a higher level, 2 if a participant has college education and 3 if the participant has a university degree. Income has been collapsed into one continuous variable of which the natural log has been taken, using the midpoints of the categories (and 1 million euro for the upper category). Experience measures the years of experience as entrepreneur, manager, and employee, respectively. Significance at the $10 \%$ level is denoted by $*, 5 \%$ by ${ }^{* *}$, and $1 \%$ by $* * *$, with t-statistics reported in parentheses. Standard errors are robust. 
Table 6: Relationship between Risk -, Loss -, and Ambiguity Aversion and Willingness to Take Risks

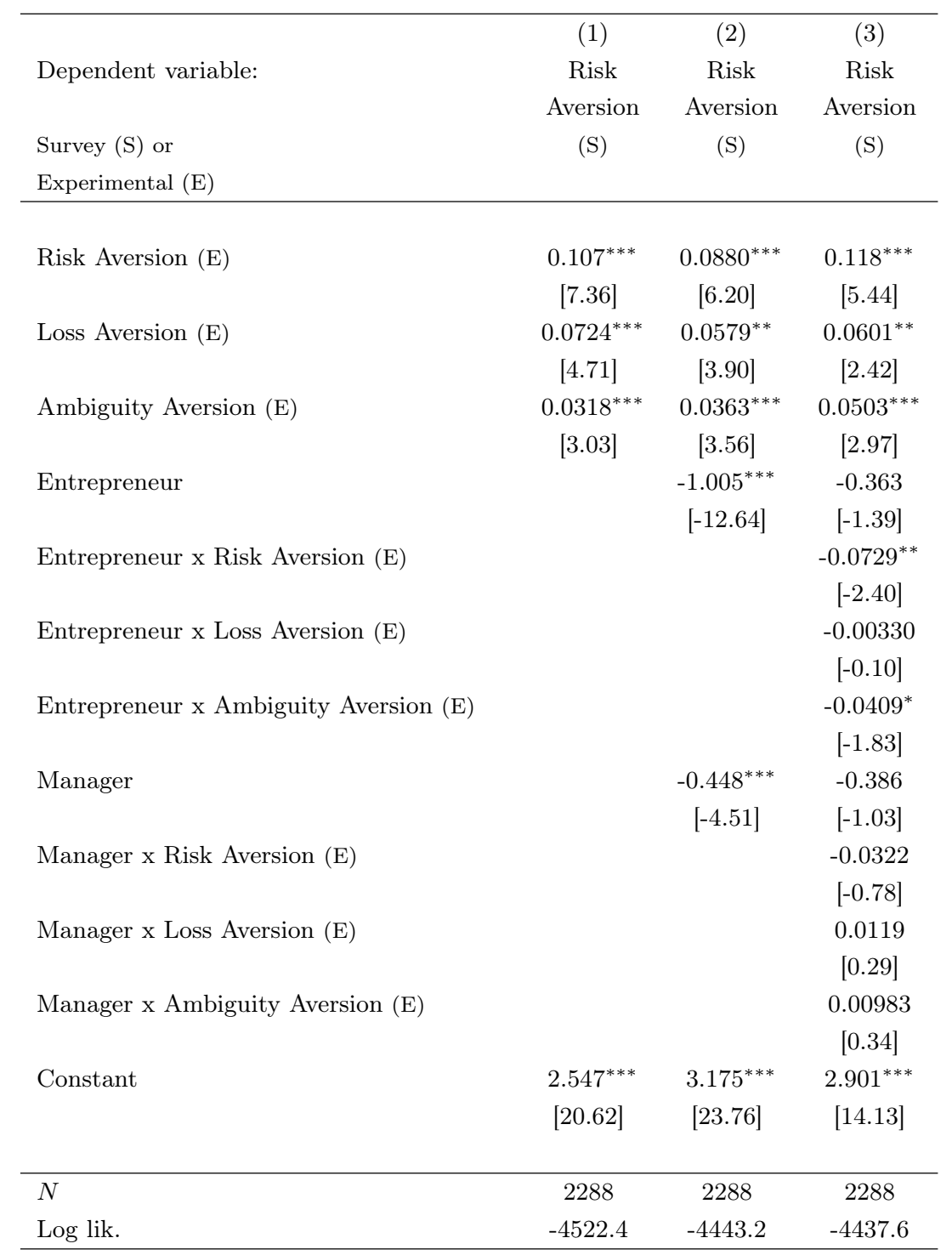

All variables have been defined earlier. Significance at the $10 \%$ level is denoted by $*, 5 \%$ by $* *$, and $1 \%$ by $* * *$. 
Table 7: Differences in Risk Attitude using Stricter Definitions of Entrepreneurs and Managers

\begin{tabular}{|c|c|c|c|c|}
\hline \multirow{3}{*}{ Dependent variable: } & (1) & $(2)$ & (3) & (4) \\
\hline & Risk & Risk & Loss & Ambiguity \\
\hline & Aversion & Aversion & Aversion & Aversion \\
\hline Survey (S) or & $(\mathrm{S})$ & $(\mathrm{E})$ & $(\mathrm{E})$ & $(\mathrm{E})$ \\
\hline \multicolumn{5}{|l|}{ Experimental (E) } \\
\hline \multirow{2}{*}{\multicolumn{5}{|c|}{$\begin{array}{l}\text { Panel A: Subsets of Entrepreneurs, } \\
\text { all Managers } \& \text { Employees }\end{array}$}} \\
\hline & & & & \\
\hline \multirow{2}{*}{ i) Incorporated $(\mathrm{N}=446)$} & $-0.702^{\mathrm{a}, \mathrm{b}}$ & $-0.442^{\mathrm{a}, \mathrm{b}}$ & $-0.400^{\mathrm{a}, \mathrm{b}}$ & 0.0772 \\
\hline & {$[-7.84]$} & {$[-3.78]$} & {$[-3.43]$} & {$[0.65]$} \\
\hline \multirow[t]{2}{*}{ ii) Above median no. of employees $(\mathrm{N}=401)$} & $-0.730^{\mathrm{a}, \mathrm{b}}$ & $-0.282^{a}$ & $-0.270^{\mathrm{a}, \mathrm{b}}$ & 0.0831 \\
\hline & {$[-7.41]$} & {$[-2.59]$} & {$[-2.46]$} & {$[0.75]$} \\
\hline \multirow[t]{2}{*}{ iii) Above median ent. income $(\mathrm{N}=377)$} & $-0.613^{\mathrm{a}, \mathrm{b}}$ & $-0.404^{\mathrm{a}, \mathrm{b}}$ & -0.109 & -0.119 \\
\hline & {$[-5.63]$} & {$[-3.86]$} & {$[-1.60]$} & {$[-0.91]$} \\
\hline \multirow[t]{2}{*}{ iv) Founder $(\mathrm{N}=757)$} & $-0.598^{\mathrm{a}, \mathrm{b}}$ & $-0.218^{a}$ & $-0.280^{\mathrm{a}, \mathrm{b}}$ & 0.0107 \\
\hline & {$[-7.71]$} & {$[-2.81]$} & {$[-3.68]$} & {$[0.75]$} \\
\hline \multirow[t]{2}{*}{ v) In survival phase (firm age $\leq 5$ years, $N=347$ ) } & $-0.640^{\mathrm{a}, \mathrm{b}}$ & $-0.257^{\mathrm{a}}$ & $-0.258^{\mathrm{a}, \mathrm{b}}$ & -0.0421 \\
\hline & {$[-6.01]$} & {$[-2.54]$} & {$[-2.65]$} & {$[-0.39]$} \\
\hline \multirow[t]{2}{*}{ vi) Not in survival phase (firm age $>5$ years, $\mathrm{N}=563$ ) } & $-0.611^{\mathrm{a}, \mathrm{b}}$ & $-0.239^{\mathrm{a}}$ & $-0.249^{\mathrm{a}, \mathrm{b}}$ & -0.00130 \\
\hline & {$[-7.44]$} & {$[-2.88]$} & {$[-2.98]$} & {$[-0.02]$} \\
\hline$\beta$ (entrepreneur) in table 5 : & $-0.614^{\mathrm{a}, \mathrm{b}}$ & $-0.254^{\mathrm{a}}$ & $-0.251^{\mathrm{a}, \mathrm{b}}$ & 0.00279 \\
\hline
\end{tabular}

Panel B: Subsets of Managers,

all Entrepreneurs \& Employees

vii) $\mathrm{CEO}$ or general manager $(\mathrm{N}=324)$

$-0.218^{\mathrm{b}, \mathrm{c}} \quad-0.274^{\mathrm{c}} \quad-0.0442^{\mathrm{b}} \quad-0.00621$

viii) $\mathrm{CEO}(\mathrm{N}=66)$

ix) Above median no. of dir. reports $(\mathrm{N}=219)$

$\mathrm{x})$ Above median man. income $(\mathrm{N}=155)$

$\left[\begin{array}{llll}-2.53] & {[-3.27]} & {[0.52]} & {[-0.08]}\end{array}\right.$

$-0.319^{\mathrm{b}, \mathrm{c}} \quad-0.367^{\mathrm{c}} \quad-0.0203^{\mathrm{b}} \quad-0.0866$

$[-2.40] \quad[-2.57] \quad[-0.40] \quad[-0.55]$

$\begin{array}{llll}-0.197^{\mathrm{b}, \mathrm{c}} & -0.259^{\mathrm{c}} & -0.0484 & 0.0830\end{array}$

$\left[\begin{array}{llll}-2.31 & {[-3.04}\end{array}\right][-0.49] \quad[0.79]$

xi) Manager in a firm that is $>15$ years old $(\mathrm{N}=316)$

$\begin{array}{llll}-0.202^{\mathrm{b}, \mathrm{c}} & -0.370^{\mathrm{c}} & -0.00958^{\mathrm{b}} & 0.00935\end{array}$

$\left[\begin{array}{llll}{[-1.97} & {[-3.22]} & {[-0.06]} & {[0.07}\end{array}\right]$

$\begin{array}{llllll}-0.22 & {[-2.86]} & {[-0.38]} & {[1.35]}\end{array}$

$\beta$ (manager) in table 5 :

$-0.194^{\mathrm{b}, \mathrm{c}}$

$-0.219^{\mathrm{c}} \quad-0.0101^{\mathrm{b}}$

0.0715

Panel C: Combinations of $A \& B B$

i) vs. viii); p-values Wald tests

$\begin{array}{llll}<0.001 & 0.57 & 0.01 & 0.67\end{array}$

ii) vs. ix); p-values Wald tests

$<0.001$

0.59

0.17

0.67

iii) vs. $\mathrm{x}$ ); $\mathrm{p}$-values Wald tests

$<0.001$

0.25

0.04

0.46

\begin{tabular}{lllll}
\hline Control variables & YES & YES & YES & YES
\end{tabular}

a) Significant difference between (subset of) entrepreneurs and employees at the $5 \%$ level (Wald test)

b) Significant difference between (subset of) entrepreneurs and (subset of) managers at the $5 \%$ level (Wald test)

c) Significant difference between (subset of) managers and employees at the $5 \%$ level (Wald test) 


\section{APPENDICES}

Appendix A: Example Survey Cover Letter (translated)

Dear relation of $\mathrm{ACE}$,

Since its establishment in 2006, the Amsterdam Center for Entrepreneurship (ACE) has been conducting high-quality research in the field of entrepreneurship. We aim to continue this ambition into the future.

That's why we have initiated a new large-scale study in collaboration with Synpact and VNONCW De Baak, which explores differences in decision-making between entrepreneurs, managers and employees.

We would greatly appreciate it if you would be willing to participate in our new unique study, which includes making choices that have real financial consequences. While your participation will predominantly be an important contribution to science, the results of this research will also be used to develop training material for entrepreneurs, managers and employees.

Our questionnaire is online and will take no longer than 20 minutes of your time. Depending on your decisions and luck, you can win an amount up to €675 if you are selected as a prize winner. To avoid any conflicts of interest, a civil-law notary will monitor the drawing of the prize winners, and will make sure that the draw obliges with all legal requirements.

We are very enthusiastic about the value of such insights and we strongly believe that the study outcomes can also be beneficial for you. We will therefore offer interested respondents the opportunity to receive a free individual report containing the main results of this study. However, for this report to be really valuable we need the participation of many people. That is, we need you.

We look forward to hearing from you. To participate please click on the link below:

$$
\text { https://uvafeb.qualtrics.com/SE/?SID=SV_2mnigp2XTFh3xXL }
$$

Can we kindly request you to finalize the survey before October 16th? Since VNO-NCW De Baak, Synpact and ACE are jointly sending out this survey, it might be that cross-postings will occur. Our sincere apologies for this in advance. We only require your participation once. 
Appendix B1: Cross-Occupational Experience of Entrepreneurs, Managers and Employees

\begin{tabular}{lccc}
\hline & Entrepreneur & Manager & Employee \\
\hline \% with Managerial Experience in the past & 70.7 & - & - \\
Level of past Managerial Experience (scale: 1-5) & 1.72 & - & - \\
\% that is also Employee now & 9.0 & - & - \\
\% that is also Entrepreneur now & - & 16.9 & 10.1 \\
Level of current entrepreneurial experience (scale: 1-8) & - & 1.81 & 1.33 \\
\% with entrepreneurial experience in the past & - & 12.1 & 8.9 \\
Level of past entrepreneurial experience (scale: 1-8) & - & 2.33 & 1.71 \\
\hline
\end{tabular}

The 'level of managerial experience' is measured based on a question about the number of directly reporting subordinates when and if entrepreneurs were managers beforehand. The answering categories that we coded 1 to 5 , respectively, are 2-5 // 6-10// 11-25// 26-50// More than 50. The 'level of entrepreneurial experience' measure is based on the categorized answers to managers and employees how many fulltime equivalent people they employed when they were entrepreneurs. This question was posed only to those who had been entrepreneurs in the past. Answer categories were: 0 // 1-4 // 5-10 // 11-25 // 26-100 // 101-250 // 251-1,000 // More than 1,000 employees. The first answer (0) corresponds with a value of 1 , the second answer (1-4) with a value of 2 , and so on. 
Appendix B2: Cross-Occupational Experience and Risk, Loss and Ambiguity Aversion

\begin{tabular}{|c|c|c|c|}
\hline \multirow{3}{*}{ Dependent variable: } & (1) & $(2)$ & $(3)$ \\
\hline & Risk & Loss & Ambiguity \\
\hline & Aversion & Aversion & Aversion \\
\hline \multicolumn{4}{|l|}{ Survey $(\mathrm{S})$ or } \\
\hline Experimental (E) & $(\mathrm{E})$ & $(\mathrm{E})$ & $(\mathrm{E})$ \\
\hline \multirow[t]{2}{*}{ Entrepreneur } & $-0.351^{* * *}$ & $-0.257^{* * *}$ & 0.0621 \\
\hline & {$[-4.30]$} & {$[-3.27]$} & {$[0.75]$} \\
\hline \multirow[t]{2}{*}{ Entrepreneur x Also employee $(\mathrm{YES}=1 ; \mathrm{NO}=0)$} & 0.198 & -0.165 & 0.0205 \\
\hline & [1.64] & {$[-1.25]$} & {$[0.15]$} \\
\hline \multirow{2}{*}{$\begin{array}{l}\text { Entrepreneur } \mathrm{x} \text { Level of past mgmt experience } \\
(=0 \text { if none })\end{array}$} & 0.0315 & 0.0355 & $-0.0525^{*}$ \\
\hline & {$[1.24]$} & {$[1.36]$} & {$[-1.80]$} \\
\hline \multirow[t]{2}{*}{ Manager } & $-0.264^{* * *}$ & -0.00826 & -0.0309 \\
\hline & {$[-3.16]$} & {$[-0.10]$} & {$[-0.34]$} \\
\hline \multirow[t]{2}{*}{ Manager $x$ Also entrepreneur $(\mathrm{YES}=1 ; \mathrm{NO}=0)$} & 0.0679 & -0.0556 & 0.0599 \\
\hline & {$[0.47]$} & {$[-0.45]$} & {$[0.42]$} \\
\hline \multirow{2}{*}{$\begin{array}{l}\text { Manager } x \text { Level of past ent. experience } \\
(=0 \text { if none })\end{array}$} & 0.00435 & -0.0169 & 0.0740 \\
\hline & {$[0.08]$} & {$[-0.37]$} & {$[1.22]$} \\
\hline \multirow[t]{2}{*}{ Employee $\mathrm{x}$ Also entrepreneur $(\mathrm{YES}=1 ; \mathrm{NO}=0)$} & -0.127 & -0.126 & -0.0921 \\
\hline & {$[-1.09]$} & {$[-1.25]$} & {$[-0.81]$} \\
\hline \multirow{2}{*}{$\begin{array}{l}\text { Employee } \mathrm{x} \text { Level of past ent. experience } \\
(=0 \text { if none })\end{array}$} & 0.00542 & 0.0113 & -0.0436 \\
\hline & {$[0.21]$} & {$[0.37]$} & {$[-1.53]$} \\
\hline Control variables & YES & YES & YES \\
\hline$N$ & 1805 & 1805 & 1805 \\
\hline Log lik. & -3967.6 & -3863.3 & -3837.4 \\
\hline Entrepreneur $=$ Manager $^{1}$ & 0.31 & $<0.01^{* * *}$ & 0.33 \\
\hline
\end{tabular}

1) This reports the p-value of the Wald test 'entrepreneur' = 'manager'.

This table reports risk -, loss -, and ambiguity aversion of enterpreneurs, managers and employees, including controls for cross-occupational experiences and interactions. All variables have been defined in Appendix Table B or before. Control variables are the same as in Table 5 . Significance at the $10 \%$ level is denoted by $*, 5 \%$ by **, and $1 \%$ by ***, with t-statistics reported in parentheses. Standard errors are robust. 


\section{Figures}

\begin{tabular}{|c|c|c|}
\hline & Option A & Option B \\
\hline Decision 1 & $€ 300$ with a probability of $50 \%$ & E25 for sure \\
\hline Decision 2 & E300 with a probability of $50 \%$ & €50 for sure \\
\hline Decision 3 & $€ 300$ with a probability of $50 \%$ & $€ 75$ for sure \\
\hline Decision 4 & $€ 300$ with a probability of $50 \%$ & $€ 100$ for sure \\
\hline Decision 5 & $€ 300$ with a probability of $50 \%$ & $€ 125$ for sure \\
\hline Decision 6 & $€ 300$ with a probability of $50 \%$ & $€ 150$ for sure \\
\hline Decision 7 & $€ 300$ with a probability of $50 \%$ & $€ 175$ for sure \\
\hline Decision 8 & $€ 300$ with a probability of $50 \%$ & $€ 200$ for sure \\
\hline Decision 9 & $€ 300$ with a probability of $50 \%$ & $€ 225$ for sure \\
\hline Decision 10 & $€ 300$ with a probability of $50 \%$ & E250 for sure \\
\hline
\end{tabular}

Looking at these 10 decisions, which of the answers below is most applicable to you? $\neq$

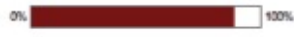

Figure 1: Measure of Risk Aversion 


\begin{tabular}{|c|c|c|}
\hline & Option A & Option B \\
\hline Decision 1 & $\begin{array}{l}\text { I lose } € 1 \text { with a probability of } 50 \% \\
\text { I gain } € 6 \text { with a probability of } 50 \%\end{array}$ & I receive $\in 0$ \\
\hline Decision 2 & $\begin{array}{l}\text { I lose } € 2 \text { with a probability of } 50 \% \\
\text { I gain } € 6 \text { with a probability of } 50 \%\end{array}$ & I receive 60 \\
\hline Decision 3 & $\begin{array}{l}\text { I lose } € 3 \text { with a probability of } 50 \% \\
\text { I gain } € 6 \text { with a probability of } 50 \%\end{array}$ & I receive 60 \\
\hline Decision 4 & $\begin{array}{l}\text { I lose } € 4 \text { with a probability of } 50 \% \\
\text { I gain } € 6 \text { with a probability of } 50 \%\end{array}$ & I receive $€ 0$ \\
\hline Decision 5 & $\begin{array}{l}1 \text { lose } € 5 \text { with a probability of } 50 \% \\
\text { I gain } € 6 \text { with a probability of } 50 \%\end{array}$ & I receive $€ 0$ \\
\hline Decision 6 & $\begin{array}{l}\text { I lose } € 6 \text { with a probability of } 50 \% \\
\text { I gain } € 6 \text { with a probability of } 50 \%\end{array}$ & I receive $€ 0$ \\
\hline Decision 7 & $\begin{array}{l}\text { I lose } € 7 \text { with a probability of } 50 \% \\
\text { I gain } € 6 \text { with a probability of } 50 \%\end{array}$ & I receive $€ 0$ \\
\hline Decision 8 & $\begin{array}{l}\text { I lose } € 8 \text { with a probability of } 50 \% \\
\text { I gain } € 6 \text { with a probability of } 50 \%\end{array}$ & I receive $\epsilon 0$ \\
\hline Decision 9 & $\begin{array}{l}\text { I lose } € 9 \text { with a probability of } 50 \% \\
\text { I gain } € 6 \text { with a probability of } 50 \%\end{array}$ & I receive 60 \\
\hline Decision 10 & $\begin{array}{l}1 \text { lose } € 10 \text { with a probability of } 50 \% \\
\text { I gain } € 6 \text { with a probability of } 50 \%\end{array}$ & I receive 60 \\
\hline
\end{tabular}

Looking at these 10 decisions, which of the answers below is most applicable to you?

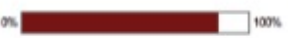

Figure 2: Measure of Loss Aversion 


\begin{tabular}{|l|l|}
\hline & \\
\hline
\end{tabular}

Looking at these 10 decisions, which of the answers below is most applicable to you? $\Rightarrow$

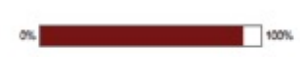

Figure 3: Measure of Ambiguity Aversion 

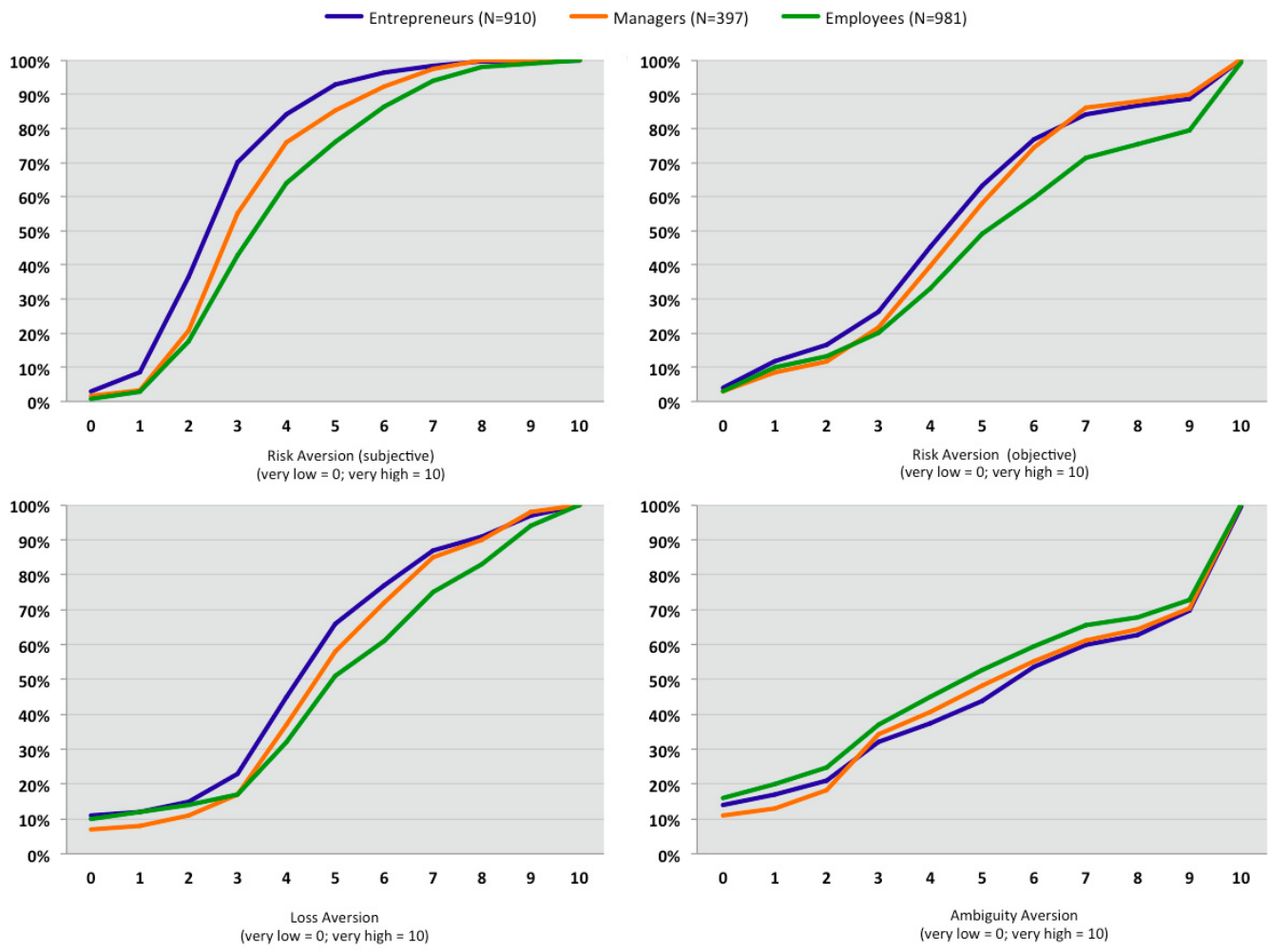

Figure 4: CDFs per measure per group 